\title{
Reproductive biology of the bat Sturnira lilium (Chiroptera, Phyllostomidae) in the Atlantic Forest of Rio de Janeiro, southeastern Brazil
}

\author{
Godoy, MSM. ${ }^{a *}$, Carvalho, WD. ${ }^{a}$ and Esbérard, CEL. ${ }^{a}$ \\ anstituto de Biologia, Universidade Federal Rural do Rio de Janeiro - UFRRJ, Rodovia BR 465 - km 07, \\ CP 74507, CEP 23890-000, Seropédica, RJ, Brazil \\ *e-mail: mairasmgodoy@hotmail.com
}

Received: February 10, 2012 - Accepted: July 11, 2013 - Distributed: December 31, 2014

(With 6 figures)

\begin{abstract}
Bats can be monoestrous or polyestrous, and seasonal or non-seasonal in their reproductive patterns. The strategy adopted by each species or population depends on the regional climate. The objective this study was to analyze reproductive data of Sturnira lilium from long-term sampling carried out in several sites in Rio de Janeiro states, southeastern Brazil. We carried out sampling in 42 sites (with altitudes ranging from sea level to $1300 \mathrm{~m}$ a.s.1.) from May 1989 to December 2011. In total, we obtained 2602 captures of S. lilium: 1242 captures of adult females, 1225 captures of adult males, and 136 captures of subadults. The sex ratio was 0.99 males: 1 female. The reproductive season varied from eight to twelve months a year, and it was not related to the total accumulated rainfall. Sturnira lilium have continuously polyestrous reproduction with postpartum estrus and pregnant females can be observed in all months except July. In the present study, the highest proportions of pregnant females were observed in the months with the highest rainfall.
\end{abstract}

Keywords: seasonality, reproductive season, rain influence, Atlantic Forest, Rio de Janeiro.

\section{Biologia reprodutiva do morcego Sturnira lilium (Chiroptera, Phyllostomidae), na Floresta Atlântica do Rio de Janeiro, sudeste do Brasil}

\begin{abstract}
Resumo
Os morcegos podem ser monoestrais ou poliestrais e sazonais ou assazonais em relação aos padrões reprodutivos. A estratégia adotada por cada espécie ou população depende do clima regional. O objetivo deste estudo foi analisar os dados reprodutivos de Sturnira lilium em amostragem de longo prazo realizado em diversos locais do Estado do Rio de Janeiro, sudeste do Brasil. De maio de 1989 a dezembro de 2011, realizamos amostragens em 42 locais (com altitudes que variam de 0 a $1300 \mathrm{~m}$ de altitude). No total, obteve 2602 capturas de $S$. lilium: 1242 fêmeas adultas, 1225 machos adultos e 136 subadultos. A proporção sexual foi 0.99 machos: 1 fêmea. A temporada reprodutiva variou de oito a doze meses por ano e não foi relacionada com o total de precipitação acumulada. Sturnira lilium apresenta reprodução contínua poliéstrica com estro pós-parto e fêmeas grávidas podem ser observadas em todos os meses, exceto o mês de julho. No presente estudo, as maiores proporções de fêmeas grávidas ocorreram nos meses com maior precipitação.
\end{abstract}

Palavras-chave: estacionalidade, época reprodutiva, influência da chuva, Mata Atlântica, Rio de Janeiro.

\section{Introduction}

Bats can be monoestrous or polyestrous, and seasonal or non-seasonal in their reproductive patterns (Fleming et al., 1972). The strategy adopted by each species or population depends on the regional climate (e.g., Wilson, 1979). Happold and Happold (1990) identified in African bats 10 strategies, considering the presence or absence of postpartum estrus: strictly seasonal monoestry, long-term seasonal monoestry, non-seasonal monoestry, bimodal polyestry with postpartum estrus, bimodal seasonal polyestry, continuous and bimodal polyestry with postpartum estrus, multimodal seasonal polyestry with postpartum estrus, multimodal continuous polyestry with postpartum estrus, multimodal continuous polyestry without postpartum estrus, and nonseasonal polyestry. There is no such comparative study for the bats of South America; and only few species had their reproductive biology analyzed in detail.

Sturnira lilium (E. Geoffroy, 1810) is distributed from Mexico to northeastern Argentina, Uruguay, and Paraguay (Simmons, 2005). In Brazil, it is present all over the country, and is classified as a common species with broad distribution (Gardner, 2007; Reis et al., 2010). Sturnira lilium is an intermediate-sized species: it weights 
on average $21 \mathrm{~g}$ and its forearm length varies from 36.6 to $45.0 \mathrm{~mm}$ (Gannon et al., 1989).

Although the reproductive biology of S. lilium has been well studied in other countries, it is still poorly known in Brazil, since it is based on local data (Mello et al., 2009), small samples (Stoner, 2001; Estrada and Coates-Estrada, 2001; Kaku-Oliveira et al., 2010) or short-term sampling (Sipinski and Reis, 1995). Mello et al. (2008a, 2009) observed, in a montane rainforest in southeastern Brazil, a positive relationship between temperature, reproduction and population size of S. lilium. The purpose of our study was to analyze reproductive data of S. lilium from longterm sampling carried out in several sites in Rio de Janeiro, southeastern Brazil.

\section{Material and Methods}

From May 1989 to December 2011, we carried out sampling in 42 sites in the state of Rio de Janeiro (Figure 1). The sampling sites vary from primary forests to urban areas, with altitudes ranging from sea level to $1300 \mathrm{~m}$ a.s.l. The state of Rio de Janeiro has an average annual rainfall of 1200 to $2200 \mathrm{~mm}$, and no months with water deficit. The average annual temperature varies from 18 to $24{ }^{\circ} \mathrm{C}$. June and July are the driest months and the highest rainfall rate occurs in December (Ramos et al., 2009).

We carried out sampling two to four nights a month. Bats were captured in mist nets (from 7 to $9 \times 2,5 \mathrm{~m}$, with $19 \mathrm{~mm}$ mesh) set up at ground level, close to food sources, trails, forest edges, and over water bodies. On each night

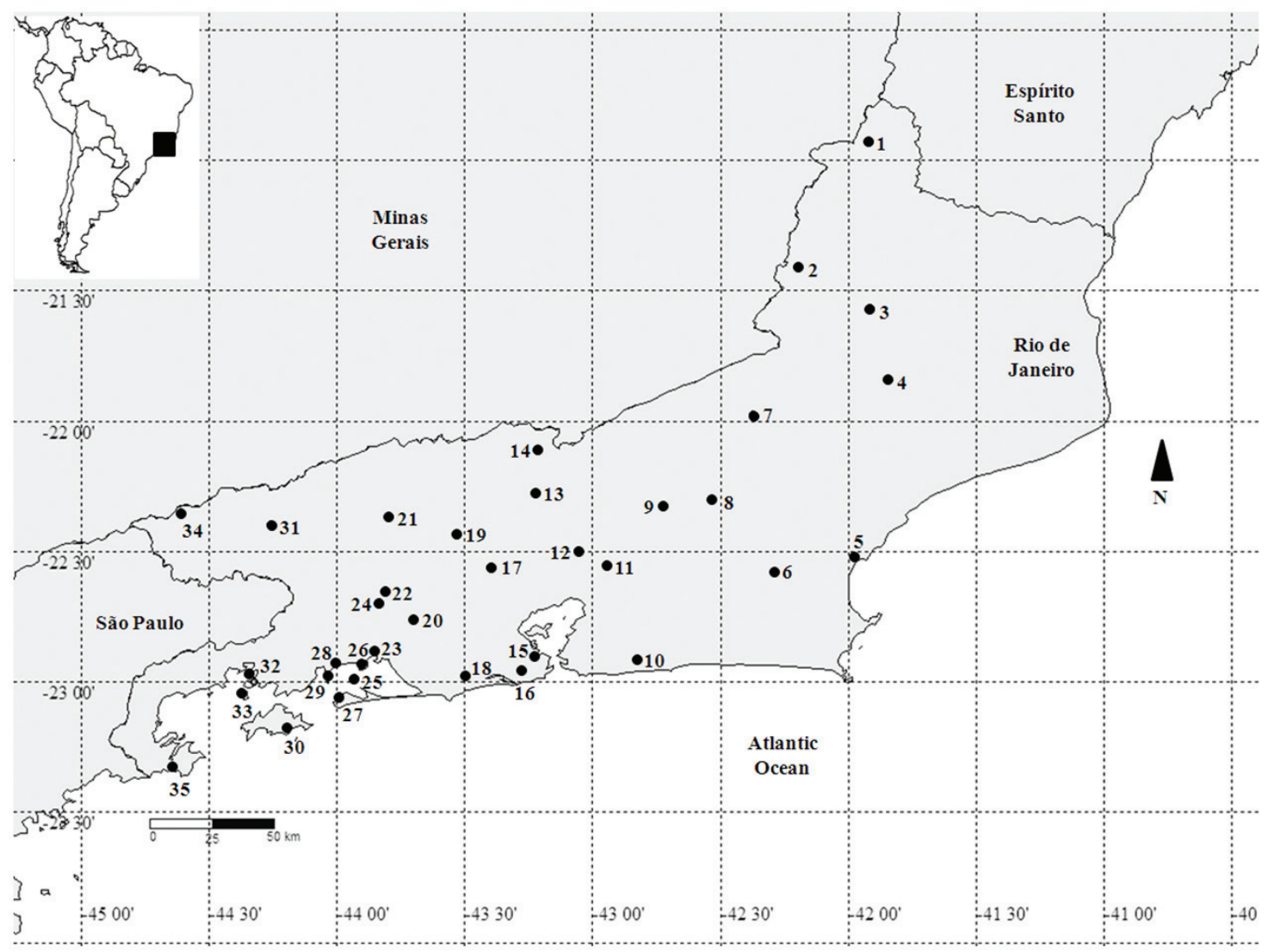

Figure 1. Localities sampled in the state of Rio de Janeiro from May 1989 to August 2011. In detail, map of South America, showing the location of the state of Rio de Janeiro. Close locations were represented as a single dot on the map. Localities: (1) Varre-Sai; (2) Miracema; (3) Cambuci; (4) Parque Estadual do Desengano, Miracema; (5) Morro de São João, Casimiro de Abreu; (6) Reserva Biológica de Poço das Antas, Silva Jardim; (7) Cantagalo; (8) Nova Friburgo; (9) Reserva Ecológica de Guapiaçu, Guapiaçú; (10) Maricá; (11) Área de Proteção Ambiental de Guapimirim and Estação Ecológica Paraíso, Guapimirim; (12) Duque de Caxias; (13) Reserva Biológica de Araras, Petrópolis; (14) Três Rios; (15) Quinta da Boa Vista, Penha and Barreira do Vasco, Rio de Janeiro; (16) Parque Guinle and Convento Jequitibá, Rio de Janeiro; (17) Estrada de Macacu and Reserva Biológica do Tinguá, Nova Iguaçú; (18) Paty do Alferes; (19) Vargem Grande, Rio de Janeiro; (20) Universidade Federal Rural do Rio de Janeiro, Seropédica; (21) Santuário de Vida Silvestre da Serra da Concórdia, Valença; (22) Ponte Coberta; (23) Coroa Grande, Mangaratiba; (24) Cacaria; (25) Ilha de Jaguanum, Mangaratiba; (26) Ilha de Itacuruça, Mangaratiba; (27) Ilha da Marambaia, Mangaratiba; (28) Vale do Sahy and Hotel Porto Belo, Mangaratiba; (29) Reserva Rio das Pedras, Mangaratiba; (30) Ilha Grande, Angra dos Reis; (31) Quatis; (32) Ilha do Capítulo, Angra dos Reis; (33) Ilha da Gipóia, Angra dos Reis; (34) Visconde de Mauá; (35) Praia do Sono, Parati. 
we set up from 10 to 16 mist nets ( 70 to $130 \mathrm{~m}$ ), which remained open all through the night in most cases. For each individual we recorded the following parameters: age, distinguishing juveniles from adults through epiphysis ossification (Anthony, 1988); fur color; sex; and reproductive condition - males were classified as having scrotal or abdominal testes, and females were classified as sexually inactive, with palpable fetus or lactant (Zortéa, 2003; Esbérard, 2012). We classified the females that were simultaneously pregnant and post-lactating, with hairless swollen nipples, without milk secretion, and without a palpable fetus as being in the second reproductive cycle (Costa et al., 2007). Up to 1997, the animals were marked with a tattoo plier and from 1998 on with plastic necklaces with colored cylinders (Esbérard and Daemon, 1999). We did not consider recaptures made on the same night.

For each month and for each (females, males, juveniles, gravid females and so on) we used capture rate, expressed as total of captures divided by the total of $\mathrm{h}^{*} \mathrm{~m}^{2}$ of nets (Straube and Bianconi, 2002), but to increase the visualization and use only three decimal places, we multiplied the values by $10^{3}$ (Esbérard, 2009).

To estimate the beginning of the reproductive season in each year, we considered only the years that had a number of captures equal or larger than ten pregnant females. The beginning of the reproductive season was considered to be at 30 days before the capture of the first female with a palpable fetus, as fetuses are detectable by palpation only after the first month of pregnancy (Costa et al., 2007; Esbérard, 2012) and pregnancy in this species lasts from three to four months (Taddei, 1976). The end of the reproductive season was considered to be at 30 days after the capture of the last lactating female. This period corresponds to the estimated duration of lactation for species of intermediate weight, between Carollia perspicillata (Linnaeus, 1758) and Artibeus jamaicensis (Leach, 1821) (Kunz and Hood,
2000). To test whether reproductive seasonality of females varies with rainfall we calculated a linear regression between the estimated duration of the reproductive season and the annual accumulated rainfall.

We use the Rayleigh test to identify frequency concentrations in a circular distributions using months as intervals (Zar, 1999). To analyze climatic factors, we used rainfall data from the Vargem Grande Meterological Station (ANA - Agência Nacional de Águas: 02242020), because it has complete historical data for the study period. Temperature data came from the Alto da Boa Vista Station (OMM: 83007, Rio de Janeiro, Ramos et al., 2009). Both stations are located close to the midpoint of the study sites. We calculated multiple linear regressions to test for a relationship between the rainfall and average temperature with the capture frequency of gravid females, lactating females and males with external testes in each month.

\section{Results}

In total we obtained 2603 captures of S. lilium: 1242 adult females, 1225 adult males, and 136 subadults. The sex ratio was 0.99 male: 1 female. Although the final equal proportion of sexes, males showed higher frequency of captures in all months except January. In all months the sum of captures resulted in an average of $191.42 \pm 87.90$ captures per month and a capture rate of $2.67 \pm 0.68$ captures $/ \mathrm{h}^{*} \mathrm{~m}^{2}$ net* $10^{3}$ (Figure 2 ). We observed subadult individuals in all months, which were more frequent in February, April and May (captures above 0.20 captures $/ \mathrm{h}^{*} \mathrm{~m}^{2}$-net* $10^{3}$ ) and less frequent in June, July and October (captures below 0.10 captures $/ \mathrm{h}^{*} \mathrm{~m}^{2}$-net* $10^{3}$ ) (Figure $3 \mathrm{~A}$ ). We observed newborns carried by their mothers in November $(n=3)$, May $(n=1)$, June $(n=1)$, and September $(n=1)$, whose forearm length varied from 16.79 to $42.10 \mathrm{~mm}$, and whose weight varied from 3.0 to $13.9 \mathrm{~g}$.

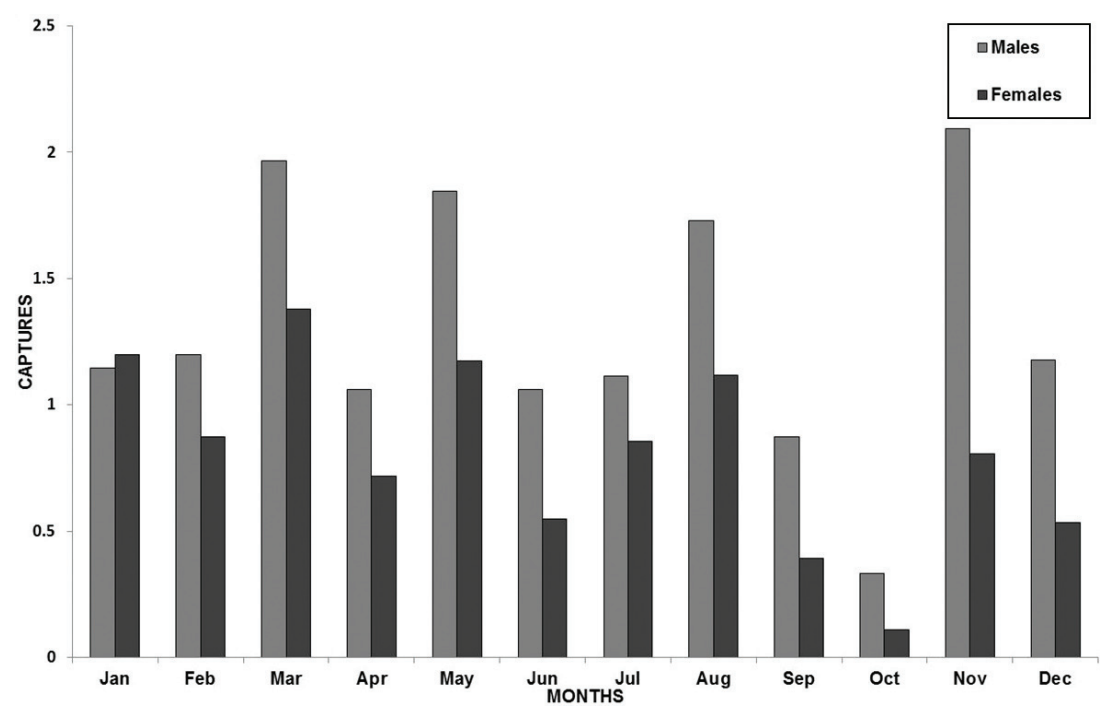

Figure 2. Number of males and females Sturnira lilium captured monthly between 1989 and 2011 in the state of Rio de Janeiro. Captures expressed as $\left(\mathrm{N} / \mathrm{h}^{*} \mathrm{~m}^{2}\right.$ of nets $) * 10^{3}$. 
We observed males with scrotal testes in all months $(r=0.106, Z=0.078, p=0.93)$ (Table 1). The concentration of males with scrotal testes exceeded the amount of males with abdominal testes from September to January, averaging $0.653 \pm 0.282$ captures $/ \mathrm{h}^{*} \mathrm{~m}^{2}$-net* $10^{3}$, while in others months average $0.472 \pm 0.162$ captures $/ h^{*} m^{2}$-net* $10^{3}$ (Figure 3B). We captured pregnant females in all months except July, averaging of $0.177 \pm 0.162$ captures $/ \mathrm{h}^{*} \mathrm{~m}^{2}$ net* $10^{3},(r=1, Z=1, p=0.512)$. The months with the highest proportion of pregnant females, September to March averaged $0.274 \pm 0.149$ captures $/ \mathrm{h}^{*} \mathrm{~m}^{2}$-net* $10^{3}$, while from April to August capture frequency of gravid females was lower $\left(0.040 \pm 0.032\right.$ captures $/ \mathrm{h}^{*} \mathrm{~m}^{2}$-net* $\left.10^{3}\right)$. We observed lactating females in all months, averaging 0.269 \pm 0.301 captures $/ \mathrm{h}^{*} \mathrm{~m}^{2}$-net* $\left.10^{3}\right)$, with peak in November $(\mathrm{r}=0.977, \mathrm{Z}=1.909, \mathrm{p}=0.055)$ (Table 1). From June to September the capture frequency of lactating females was reduced $\left(>0.100\right.$ captures $/ \mathrm{h}^{*} \mathrm{~m}^{2}$-net* $\left.10^{3}\right)$ while from October to May averaged $0.376 \pm 0.474$ captures $/ \mathrm{h}^{*} \mathrm{~m}^{2}$ net* $10^{3}$. Females simultaneously pregnant and lactating were observed in all months but July, with high frequency in December. Post-lactating females were observed in all months with increased frequency of capture from March to June (Figure 4).

We observed a significant multiple regression between the accumulated rainfall and average temperature with capture frequency of pregnant females $\left(\mathrm{R}^{2}=0.725\right.$; $\mathrm{F}=11.892 ; \mathrm{p}=0.003)$ with rainfall $(\mathrm{p}=0.046)$ being the best descriptor than average temperature $(p=0.229)$. We do not observed a significant multiple regression between these two climatic variables with lactating females $\left.\mathrm{R}^{2}=0.407 ; \mathrm{F}=3.086 ; \mathrm{p}=0.095\right)$ or with males with external testes $\left(\mathrm{R}^{2}=0.145 ; \mathrm{F}=0.761 ; \mathrm{p}=0.495\right)$ (Figure 5). The reproductive season varied from eight to twelve months a year (Table 2), and it was not related to the total accumulated rainfall $\left(\mathrm{R}^{2}=0.155 ; \mathrm{F}=0.321\right.$; $\mathrm{p}=0.58)$ (Figure 6).

\section{Discussion}

The sex ratio varied throughout the year and was skewed towards males. In harem species a sexual proportion skewed to females can be expected (Mello and Fernandez, 2000),

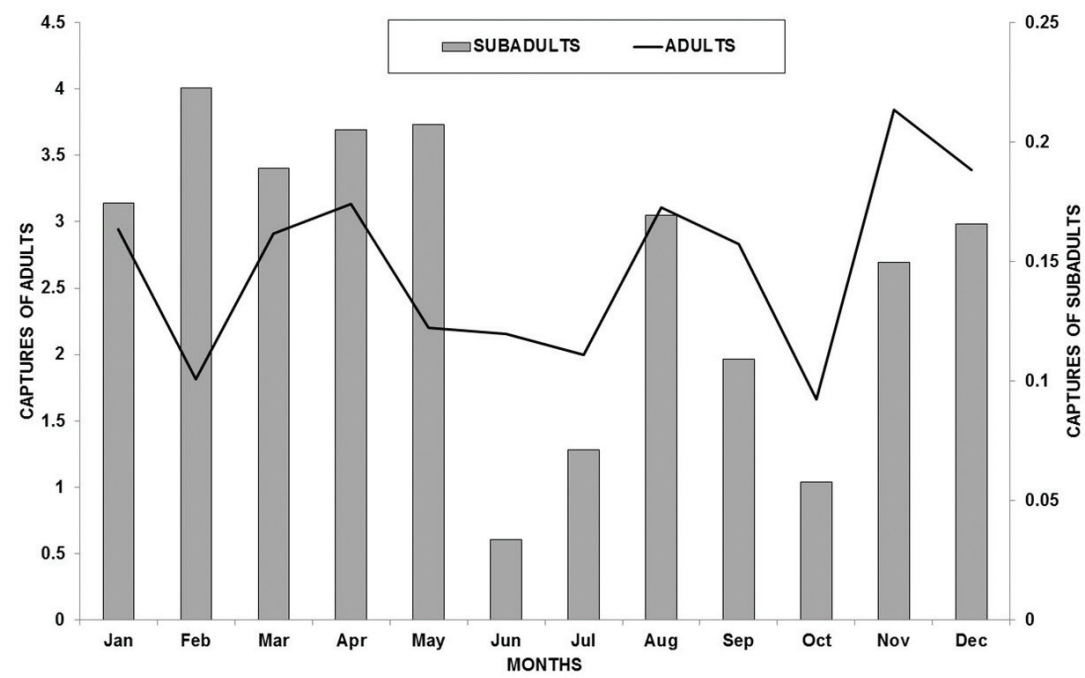

Figure 3. Capture of adults and subadults of Sturnira lilium captured monthly from 1989 to 2011 in the state of Rio de Janeiro. Captures expressed as $\left(\mathrm{N} / \mathrm{h}^{*} \mathrm{~m}^{2} \text { of nets }\right)^{*} 10^{3}$.

Table 1. Analyzes of circular statistics for the occurrence of phenological peaks for lactating and pregnant females and males with scrotal testes of Sturnira lilium. The Rayleigth's test was conducted with significance level of 0.05 .

\begin{tabular}{ccc}
\hline Lactating females & Mean angle $(\mu)$ & $\mathbf{3 3 0}^{\circ}$ (November) \\
\hline & Circular standard deviation & $12.347^{\circ}$ \\
& Length vector $(\mathrm{r})$ & 0.977 \\
& Rayleigth's test $(\mathrm{p})$ & 0.023 \\
\hline Pregnant females & Mean angle $(\mu)$ & $\mathbf{3 1 5}^{\circ}$ (November) \\
\hline & Circular standard deviation & - \\
& Length vector $(\mathrm{r})$ & 1 \\
& Rayleigth's test $(\mathrm{p})$ & 0.512 \\
\hline Males with scrotal testes & Mean angle $(\mu)$ & $\mathbf{4 5}^{\circ}$ (May) \\
\hline & Circular standard deviation & $121.445^{\circ}$ \\
& Length vector $(\mathrm{r})$ & 0.106 \\
& Rayleigth's test $(\mathrm{p})$ & 0.93 \\
\hline
\end{tabular}



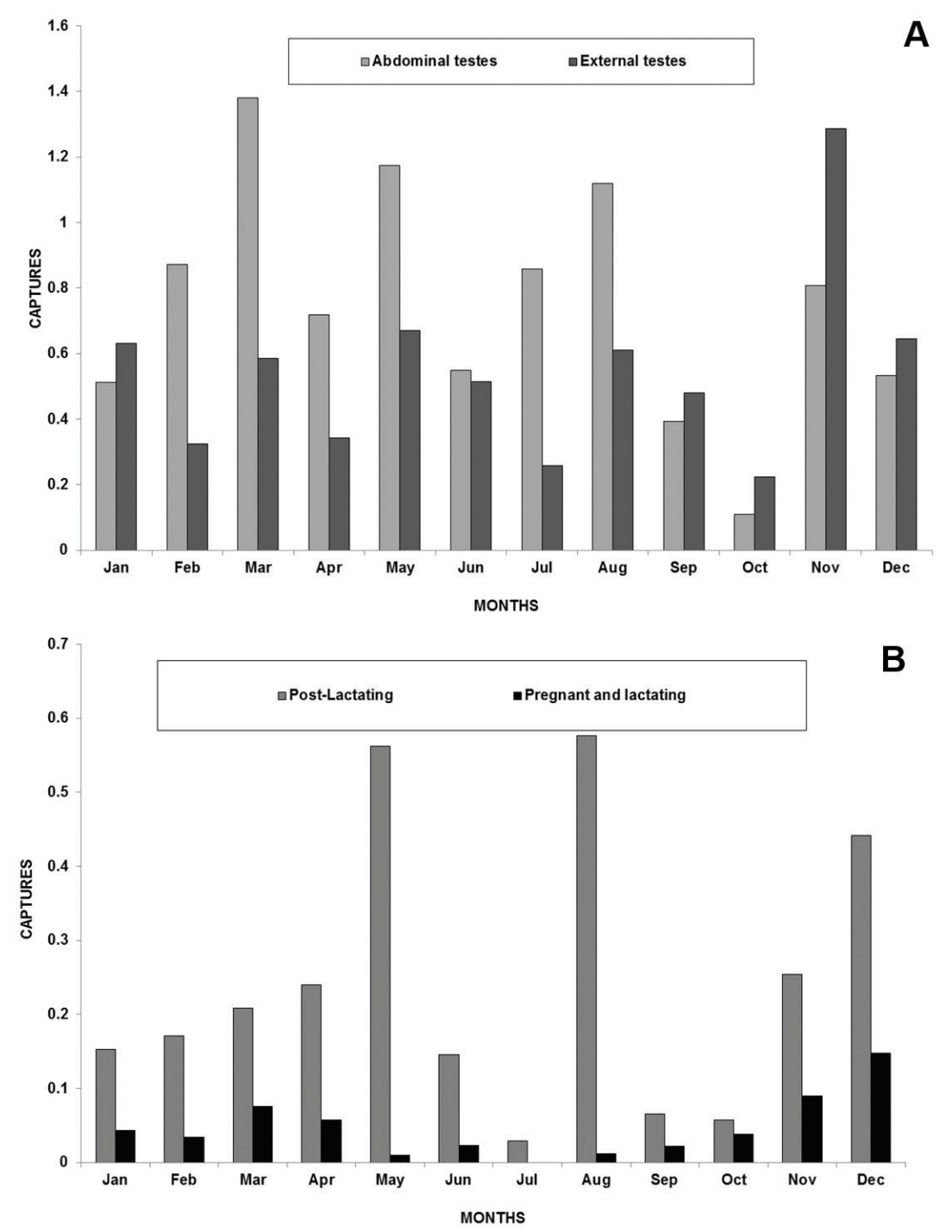

Figure 4. Captures of males e females of Sturnira lilium captured monthly from 1989 to 2011 in the state of Rio de Janeiro: (A) males with scrotal and abdominal testes (B) post-lactating and simultaneously pregnant and lactating. Captures expressed as $\left(\mathrm{N} / \mathrm{h}^{*} \mathrm{~m}^{2}\right.$ of nets)* $10^{3}$.

Table 2. Estimated reproductive season of female Sturnira lilium based on females with a palpable fetus and lactating females captured monthly from 1989 to 2011 in the state of Rio de Janeiro.

\begin{tabular}{cccccccccccccc}
\hline Years & N* & Jan & Feb & Mar & Apr & May & Jun & Jul & Aug & Sep & Oct & Nov & Dec \\
\hline 1991 & 11 & X & X & X & X & & & & & & X & X & X \\
1992 & 14 & X & X & X & X & X & X & X & & & X & X & X \\
1993 & 32 & X & X & X & X & & & & & & X & X & X \\
1994 & 24 & X & X & X & X & X & & & X & X & X & X & X \\
1995 & 19 & X & X & X & X & X & X & X & X & X & X & X & X \\
1996 & 28 & X & X & X & X & X & & & & X & X & X & X \\
1997 & 13 & X & X & X & X & X & X & X & X & X & X & X & X \\
2001 & 13 & X & X & X & X & & & & & X & X & X & X \\
2002 & 13 & X & X & X & X & & & & & & X & X & X \\
2004 & 12 & X & X & X & X & X & X & X & X & X & X & X & X \\
2005 & 75 & X & X & X & X & X & X & X & & & & X & X \\
2007 & 13 & X & X & X & X & & & & & & X & X & X \\
2011 & 25 & X & X & X & X & X & X & X & X & X & X & X & X \\
\hline
\end{tabular}



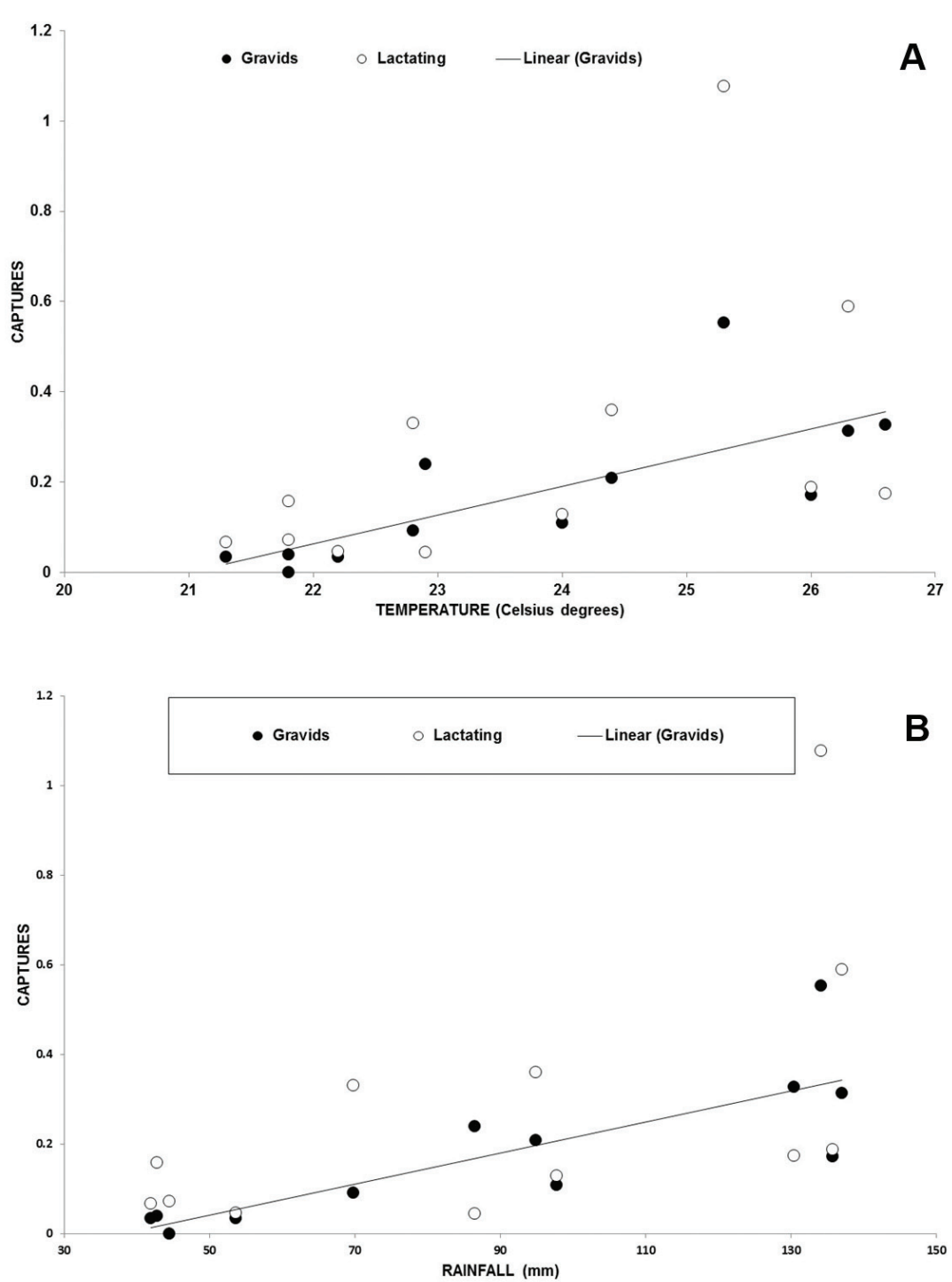

Figure 5. Relationship between the percentages of pregnant and lactating female of Sturnira lilium captured monthly from 1989 to 2011 in the state of Rio de Janeiro with (A) average temperature (B) rainfall. Captures expressed as (N/h* $\mathrm{m}^{2}$ of nets) $* 10^{3}$.

but this data, using long term sampling and a great variety of locals probably inhibit this difference as obtained by Costa et al. (2010) in other harem bat species. Subadult bats were more netted from November to February, period that is expect the independence of the youngs borned in each year and less frequent from May to August, when few females showed reproductive activity. We observed males with scrotal testes in all months: a small frequency from February to August and a large frequency from September to January. In tropical species, the production of male gametes needs to be synchronized with female activity; in polyestrous species, individuals with scrotal testes can be captured at any time of the year (Krutzsch, 2000). Adult males of Artibeus jamaicensis Leach, 1821, in Panama, have their spermatogenesis extended when females are receptive during postpartum estrus (Handley et al., 1991). Based on our study, we believe that the same might happen to male $S$. lilium in the state of Rio de Janeiro. Some authors say that testes location is not a good indicator of male reproductive activity, since the spermatic activity is continuous (Fabián and Marques, 1989; Moraes, 2008). Other authors suggest the use of other external indicators of active reproduction, such as behavior, glands, and odors (Krutzsch, 2000; Mello et al., 2009). However, in the present study, the higher proportion of males with scrotal testes was synchronized with the proportion of potentially receptive females (lactating and post-lactating), indicating that the more females are in estrus, the more males will show maximum sperm production. 


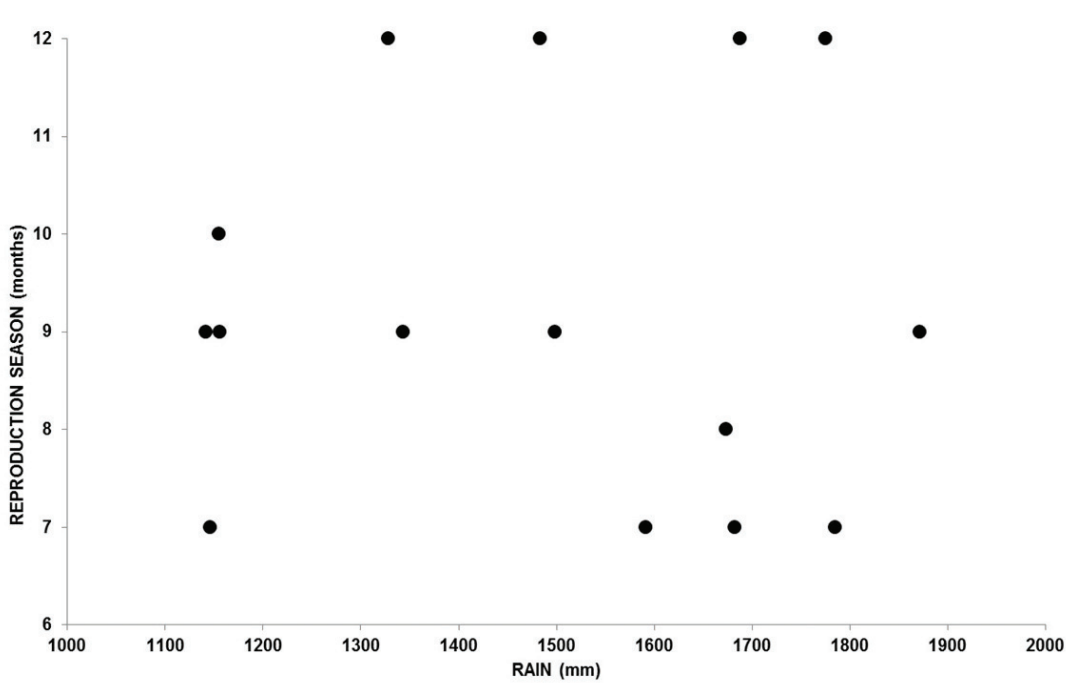

Figure 6. Variation of the estimated duration of the reproductive season of Sturnira lilium from 1989 to 2011 in the state of Rio de Janeiro for the years with more than 10 sexually active females captured the with total accumulated rainfall.

Female S. lilium have continuously polyestrous reproduction with postpartum estrus (Happold and Happold, 1990). Pregnant females are observed in all months but July, and lactating females are observed in all months. Stoner (2001) studied S. lilium in Costa Rica and captured pregnant females from February to May and in December, and lactating females from February to June, and in October and December, corroborating a bimodal polyestrous pattern. Estrada and Coates-Estrada (2001) observed the same pattern in Mexico.

Tropical bats, such as Anoura geoffroyi Gray, 1838, may have monoestrous cycles as a response to food availability (Baumgarten and Vieira, 1994). However, the most common pattern is a response to local climate, as observed in Artibeus lituratus Olfers, 1818, which varies from bimodal polyestrous in Central America (Fleming et al., 1972) and at low altitudes in southeastern Brazil (Reis, 1989) to seasonal monoestrous at altitudes above 1,000 m a.s.l. in southeastern Brazil (Duarte and Talamoni, 2010). Bimodal polyestry was also observed in Platyrrhinus lineatus E. Geoffroy, 1810 at the same latitude of the present study (Costa et al., 2007) and in other species in tropical areas (Fleming et al., 1972; Wilson, 1979; Willig, 1985; Granham, 1989; Stoner, 2001; Estrada and Coates-Estrada, 2001).

We observed higher frequency of pregnant females of S. lilium in September, which suggests a beginning to the reproductive season in June or July. Lactation requires higher energy costs in comparison to other reproductive activities (e.g., Gitleman and Thompson, 1988; Heideman, 2000; Korine et al., 2004; Melo et al., 2012). Hence, reproduction in bats should be synchronized so that lactation occurs when food availability is highest, which usually coincides with the period of the highest rainfall (Janzen, 1967; Fleming et al., 1972; Willig, 1985; Heideman,
1995; Estrada and Coates-Estrada, 2001; Zortéa, 2003; Costa et al., 2007). The months in which pregnancy and lactation of this species occur more frequently at this latitude coincide with the highest rainfall, supporting the importance of synchronizing reproduction with the highest environmental productivity. However, there was no relationship between the percentage of lactating females and climate variables. In a study on S. lilium in southeastern Brazil at a subtropical latitude, Mello et al. (2009) observed a relationship between temperature and the number of pregnant and lactating females. In the present study, the highest proportions of pregnant and lactating females were observed in the months with highest rainfall. However, as the rainiest months are the hottest, it is difficult to distinguish the role of each variable in determining the reproductive seasonality of $S$. lilium.

We observed a relationship between accumulated rainfall and average temperature and the frequency of pregnant females. Mello et al. (2009) observed that, although S. lilium did not have its reproduction synchronized with rainfall nor fruit availability, births occurred in the rainy season. These authors suggest that temperature has the strongest influence on the reproduction of S. lilium in montane forests.

Sexually active females could be observed from eight to twelve months, similarly to what was observed for P. lineatus in the same study sites (Costa et al., 2007). Longer reproductive seasons were not related to accumulated rainfall. Only through long-term sampling at different conditions it will be possible to identify the strategies adopted by different populations. One-year sampling is often little representative. Such variation evidences the adaptability of S. lilium to annual and multiannual rainfall cycles, as already observed in other species (Bronson, 1985) and evidence that local variations could also be expected. 
Fruits of Solanaceae are a yearlong food source for mammals (Elias et al., 2003; Iudica and Bonaccorso, 1997; Mello et al., 2008b), mainly during the dry season, when the availability of other fruits is scarce (Dalponte and Lima, 1999). Other studies have already shown a strong association between $S$. lilium and plants of the genus Solanum (Uieda and Vasconcellos-Neto, 1985; Iudica and Bonaccorso, 1997; Herrera et al., 2001; Mello et al., 2008a, b, 2009). Flowering and fruiting of these species may vary from September to March in tropical areas (Vignoli-Silva and Mentz, 2005; Penhalber and Montovani, 1997; Santos and Kinoshita, 2003), with flowering in the end of the dry season (July-September) and fruiting in the beginning of the rainy season (October-November). This phenology coincides with the peaks of lactating females observed in the present study, which suggests the synchronization of most pregnancies with the period of the highest food availability in the state of Rio de Janeiro.

Hence, we conclude that $S$. lilium has non-seasonal polyestry with postpartum estrus at the studied latitude $\left(23^{\circ} \mathrm{S}\right)$. Most captures of pregnant females coincided with the months of the highest rainfall. The duration of the reproductive season varies annually and is independent of the accumulated rainfall.

\section{Acknowledgements}

To Instituto Estadual de Florestas, Instituto Brasileiro de Meio Ambiente, Centro de Primatologia do Rio de Janeiro, Secretaria Municipal de Meio Ambiente do Município do Rio de Janeiro, Secretaria de Agricultura e Pesca de Casimiro de Abreu, Reserva Rio das Pedras, Empresa Brasileira de Pesquisa Agropecuária, Club Méd, Secretaria de Saúde de Angra dos Reis, Fazenda da Gipóia-SOGIM, Fazenda Portobello, Reserva Biológica Poço das Antas, Associação Mico Leão Dourado, Fazenda Ventania, Fundação RIOZOO, Fazenda Ouro Verde, Fazendas Reunidas São João, Fazenda da Barra, Reserva Guapiaçú, Reserva Ecológica Rio das Pedras, Fazenda Marimbondo and Centro de Adestramento da Marinha for permission to collections and support granted; to Instituto Biomas, SOS Mata Atlântica and Conservation International through to Project "Critical ecosystem Partnership Fund" (CEPF - Aliança para Conservação da Mata Atlântica); Bat Conservation International and Secretaria de Educação de Quissamã; NUPEM/UFRJ, Pró-Reitoria de Pós-Graduação da UFRRJ and to Programa de Pós-Graduação em Biologia Animal of UFRRJ for financial help; A. Motta, T. Jordão-Nogueira, J.L. Luz, L.M. Costa, and other members of Laboratório de Diversidade de Morcegos for their support in field. to CAPES for master scholarship granted to M.S.M. Godoy and doctorate scholarship to W.D. Carvalho; to CNPq for the "Productivity in Research" fellowship (process \# 301061/2007-6) and to FAPERJ for the "Young Scientist" scholarship to C.E.L. Esbérard; to FAPERJ and CNPq for financing the field work (processes \# E-16/170.449/07 and \# 471983/2007-1). This work was authorized through a special collection permit granted by the IBAMA (Processes \# 1755/89- SUPES/RJ/IBAMA and 4156/95-46 AC-SUPES/
DF/IBAMA) and a permanent SISBIO collection license (\# 10356-1).

\section{References}

ANTHONY, ELP., 1988. Age determination in bats. In KUNZ, TH. Ecological and behavioral methods for the study of bats. Washington: Smithsonian Institution. p. 47-58.

BAUMGARTEN, JE. and VIEIRA, EM., 1994. Reproductive seasonality and development of Anoura geoffroyi (Chiroptera: Phyllostomidae) in central Brazil. Mammalia, vol. 58, no. 3, p. 415-422. http://dx.doi.org/10.1515/mamm.1994.58.3.415.

BRONSON, FH., 1985. Mammalian reproduction: an ecological perspective. Biology of Reproduction, vol. 32, no. 1, p. 1-26. http:// dx.doi.org/10.1095/biolreprod32.1.1. PMid:3882162

COSTA, LM., ALMEIDA, JC. and ESBÉRARD, CEL., 2007. Dados de reprodução de Platyrrhinus lineatus em estudo de longo prazo no estado do Rio de Janeiro. Iheringia. Série Zoologia, vol. 97, p. 175-176.

COSTA, LM., LOURENÇO, EC., ESBÉRARD, CE. and SILVA, RM., 2010. Colony size, sex ratio and cohabitation in roosts of Phyllostomus hastatus (Pallas) (Chiroptera: Phyllostomidae). Revista Brasileira de Biologia = Brazilian Journal of Biology, vol. 70, no. 4, p. 1047-1053. http://dx.doi.org/10.1590/S151969842010000500019. PMid:21180912

DALPONTE, JC. and LIMA, ES., 1999. Disponibilidade de frutos e a dieta de Lycalopex vetulus (Carnivora - Canidae) em um cerrado de Mato Grosso, Brasil. Revista Brasileira de Botânica = Brazilian. Le Journal de Botanique, vol. 22, no. 2, p. 325-332.

DUARTE, APG. and TALAMONI, SA., 2010. Reproduction of the large fruit - eating bat Artibeus lituratus (Chiroptera: Phyllostomidae) in a Brazilian Atlantic forest area. Mammalian Biology, vol. 75, no. 4, p. 320-325. http://dx.doi.org/10.1016/j. mambio.2009.04.004.

ELIAS, SRM., ASSIS, RM., STACCIARINI-SERAPHIN, E. and REZENDE, MH., 2003. Anatomia foliar em plantas jovens de Solanum lycocarpum A.St.-Hil. (Solanaceae). Revista Brasileira de Botânica = Brazilian. Le Journal de Botanique, vol. 26, no. 2, p. 169-174.

ESTRADA, A. and COATES-ESTRADA, R., 2001. Species composition and reproductive phenology of bats in a tropical landscape at Los Tuxtlas, México. Journal of Tropical Ecology, vol. 17, no. 05, p. 627-646. http://dx.doi.org/10.1017/ S026646740100147X.

ESBÉRARD, CEL. and DAEMON, C., 1999. Novo método para marcação de morcegos. Chiroptera Neotropical, vol. 5, no. 1-2, p. 116-117.

ESBÉRARD, CEL., 2009. Capture sequence and relative abundance of bats during surveys. Zoologia, vol. 26, no. 1, p. 103-108. http:// dx.doi.org/10.1590/S1984-46702009000100016.

ESBÉRARD, CEL., 2012. Reproduction of Phylloderma stenops in captivity (Chiroptera, Phyllostomidae). Revista Brasileira de Biologia = Brazilian Journal of Biology, vol. 72, no. 1, p. 171-174. http://dx.doi.org/10.1590/S1519-69842012000100020. PMid:22437398

FABIÁN, ME. and MARQUES, RV., 1989. Contribuição ao conhecimento da biologia reprodutiva de Molossus molossus Pallas, 1766 (Chiroptera, Molossidae). Revista Brasileira de Zoologia, vol. 6, no. 4, p. 603-610. http://dx.doi.org/10.1590/ S0101-81751989000400005. 
FLEMING, TH., HOOPER, ET. and WILSON, DE., 1972. Three Central American communities: structure, reproductive cycles and movements patterns. Ecology, vol. 53, no. 4, p. 555-569. http:// dx.doi.org/10.2307/1934771.

GANNON, MR., WILLIG, MR. and JONES JUNIOR, JK., 1989. Sturnira lilium. Mammalian Species, vol. 333, no. 333, p. 1-5. http://dx.doi.org/10.2307/3504237.

GARDNER, AL., 2007. Mammals of South America. Chicago: The University of Chicago Press. 669 p. vol. 1. Marsupials, Xenarthrans, Shrews, and Bats.

GITLEMAN, JL. and THOMPSON, SD., 1988. Energy allocation in mammalian reproduction. American Zoologist, vol. 28, p. 863-875.

GRANHAM, GL., 1989. Seasonality of reproduction in Peruvian bats. Fildiana, vol. 39, p. 173-186.

HANDLEY, COJR Jr., WILSON, DE. and GARDNER, AL., 1991. Demography and natural history of the common fruit bat, Artibeus jamaicensis, on Barro Colorado Island, Panamá. Smithsonian Contributions to Zoology, vol. 511, no. 511, p. 1-173. http://dx.doi.org/10.5479/si.00810282.511.

HAPPOLD, DCD. and HAPPOLD, M., 1990. Reproductive strategies of bats in Africa. Journal of Zoology, vol. 222, no. 4, p. 557-583. http://dx.doi.org/10.1111/j.1469-7998.1990.tb06014.x.

HEIDEMAN, PD., 1995. Synchrony and seasonality of reproduction in tropical bats. Symposia of the Zoological Society of London, vol. 67 , p. 151-165.

HEIDEMAN, PD., 2000. Environmental regulation of reproduction. In CRICHTON, EG. and KRUTZSCH, $\mathrm{PH}$. The reproductive biology of bats. London: Academic Press. p. 469-499.. http:// dx.doi.org/10.1016/B978-012195670-7/50012-6.

HERRERA, LG., HOBSON, KA., MANZO, A., ESTRADA, D., SÁNCHEZ-CORDERO, V. and MÉNDEZ, G., 2001. The role of fruits and insects in the nutrition of frugivorous bats: evaluating the use of stable isotope models. Biotropica, vol. 33, no. 2 , p. 520-528.

IUDICA, CA. and BONACCORSO, FJ., 1997. Feeding of the bat, Sturnira lilium, on fruits of Solanum riparium influences dispersal of this pioneer tree in forests of northwestern Argentina. Studies on Neotropical Fauna and Environment, vol. 32, no. 1, p. 4-6. http://dx.doi.org/10.1076/snfe.32.1.4.13464.

JANZEN, DH., 1967. Synchronization of sexual reproduction of trees with the dry season in Central America. Evolution; International Journal of Organic Evolution, vol. 21, no. 3, p. 620-637. http://dx.doi.org/10.2307/2406621.

KAKU-OLIVEIRA, NY., MUNSTER, LC., RUBIO, MBG. and PASSOS, FC., 2010. Reprodução em cinco espécies de morcegos filostomídeos na Reserva Natura do Salto Morato, Guaraqueçaba, Paraná. Chiroptera Neotropical, vol. 16, no. 1, p. 22-24.

KORINE, C., SPEAKMAN, J. and ARAD, Z., 2004. Reproductive energetics of captive and free-ranging Egyptian fruit bats (Rousettus aegyptiacus). Ecology, vol. 85, no. 1, p. 220-230. http://dx.doi. org/10.1890/02-0632.

KUNZ, TH. and HOOD, WR., 2000. Parental care and postnatal growth in the Chiroptera. In CRICHTON, EG. and KRUTZSCH, FP. Reproductive biology of bats. Boston: Academic Press. p. 415-468.. http://dx.doi.org/10.1016/B978-012195670-7/50011-4.

KRUTZSCH, P., 2000. Anatomy, physiology and ciclicity of the male reproductive tract. In CRICHTON, EG. and KRUTZSCH, FP. Reproductive biology of bats. Boston: Academic Press. p. 91-155.. http://dx.doi.org/10.1016/B978-012195670-7/50005-9.
MELO, BES., BARROS, MS., CARVALHO, TF., AMARAL, TS. and FREITAS, MB., 2012. Energy reserves of Artibeus lituratus (Chiroptera: Phyllostomidae) in two areas with different degrees of conservation in Minas Gerais, Brazil. Revista Brasileira de Biologia = Brazilian Journal of Biology, vol. 72, no. 1, p. 181187. http://dx.doi.org/10.1590/S1519-69842012000100022. PMid:22437400

MELLO, MAR. and FERNANDEZ, FAS., 2000. Reproductive ecology of the bats Carollia perspicillata (Chiroptera: Phyllostomidae) in a fragment of the Brazilian Atlantic coastal forest. Zeitschrift fur Saugetierkunde, vol. 65, p. 340-349.

MELLO, MAR., KALKO, EKV. and SILVA, WR., 2009. Ambient temperature is more important than food availability in explaining reproductive timing of the bat Sturnira lilium (Mammalia: Chiroptera) in a montane Atlantic Forest. Canadian Journal of Zoology, vol. 87, no. 3, p. 239-245. http://dx.doi.org/10.1139/Z09-010.

MELLO, MAR., KALKO, EKV. and SILVA, WR., 2008a. Diet and abundance of the bat Sturnira lilium (Chiroptera) in a Brazilian montane Atlantic Forest. Journal of Mammalogy, vol. 89, no. 2, p. 485-492. http://dx.doi.org/10.1644/06-MAMM-A-411R.1.

MELLO, MAR., KALKO, EKV. and SILVA, WR., 2008b. Movements of the bat Sturnira lilium and its role as a seed disperser of Solanaceae in the Brazilian Atlantic Forest. Journal of Tropical Ecology, vol. 24, no. 2, p. 225-228. http://dx.doi. org/10.1017/S026646740800480X.

MORAES, DB., 2008. Morfologia e morfometria testicular em morcego insetivoro (Molossus molossus Pallas, 1776) (Chiroptera, Molossidae). Viçosa: Universidade Federal de Viçosa. 91 p. Dissertação de Mestrado em Biologia Geral.

PENHALBER, EF. and MONTOVANI, V., 1997. Floração e chuva de sementes em mata secundária em São Paulo, SP. Revista Brasileira de Botânica = Brazilian. Le Journal de Botanique, vol. 20, no. 2, p. 205-220.

RAMOS, AM., SANTOS, LAR. and FORTES, LTG., 2009. Normais Climatológicas do Brasil 1961-1990. Brasília: Instituto Nacional de Meteorologia. $466 \mathrm{p}$.

REIS, SF., 1989. Biologia Reprodutiva de Artibeus lituratus (Chiroptera: Phyllostomidae). Revista Brasileira de Biologia = Brazilian Journal of Biology, vol. 49, no. 2, p. 369-372.

REIS, NR., PERACCHI, AL., FREGONEZI, MN. and ROSSANEIS, BK., 2010. Mamíferos do Brasil: guia de identificação. Rio de Janeiro: Technical Books. 560 p.

SANTOS, K. and KINOSHITA, LS., 2003. Flora arbustivoarbórea do fragmento de floresta estacional semidecidual do Ribeirão Cachoeira, município de Campinas, SP. Acta Botânica Brasilica, vol. 17, no. 3, p. 325-341. http://dx.doi.org/10.1590/ S0102-33062003000300001.

SIMMONS, NB., 2005. Order Chiroptera. In WILSON, DE. and REEDER, DM. Mammal species of the world: a taxonomic and geographic reference. Baltimore: Johns Hopkins University Press. p. 312-529.

SIPINSKI, EAB. and REIS, NR., 1995. Dados ecológicos dos quirópteros da Reserva Volta Velha, Itapoá, Santa Catarina, Brasil. Revista Brasileira de Zoologia = Zoologia, vol. 12, no. 3, p. 519-528.

STRAUBE, FC. and BIANCONI, GV., 2002. Sobre a grandeza e a unidade utilizada para estimar esforço de captura com utilização de rede-de-neblina. Chiroptera Neotropical, vol. 8, no. $1-2$, p. $150-152$. 
STONER, KE., 2001. Differential habitat use and reproductive patterns of frugivorous bats in tropical dry forest of northwestern Costa Rica. Canadian Journal of Zoology, vol. 79, no. 9, p. 16261633. http://dx.doi.org/10.1139/z01-105.

TADDEI, VA., 1976. The reproduction of some Phyllostomidae (Chiroptera) from the northwestern region of the state of São Paulo. Boletim de Zoologia da Universidade de São Paulo, vol. 1, p. 313-330.

UIEDA, W. and VASCONCELLOS-NETO, J., 1985. Dispersão de Solanum spp. (Solanaceae) por morcegos, na região de Manaus, AM, Brasil. Revista Brasileira de Zoologia = Zoologia, vol. 2, no. 7, p. $449-458$.

VIGNOLI-SILVA, M. and MENTZ, LA., 2005. O gênero Bouchetia Dunal (Solanaceae) no Rio Grande do Sul, Brasil. Iheringia. Série Botânica, vol. 60, no. 1, p. 107-112.
WILLIG, WR., 1985. Reproductive patterns of bats from Caatingas and Cerrado biomes in Northeast Brazil. Journal of Mammalogy, vol. 66, no. 4, p. 668-681. http://dx.doi.org/10.2307/1380793.

WILSON, DE., 1979. Reproductive patterns. In BAKER, RJ., JONES JK. and CARTER, DC. Biology os bats of the New World Family Phyllostomatidae. Special Publications Museum Texas Tech University. p. 317-378. vol. 16. Part III.

ZAR, JH., 1999. Biostatistical analysis. New Jersey: Prentice Hall. 663 p.

ZORTÉA, M., 2003. Reproductive patterns and feeding habits of three nectarivorous bats (Phyllostomidae: Glossophaginae) from the Brazilian Cerrado. Revista Brasileira de Biologia = Brazilian Journal of Biology, vol. 63, no. 1, p. 159-168. http:// dx.doi.org/10.1590/S1519-69842003000100020. PMid:12914427 